\title{
PENGARUH GEOGEBRA TERHADAP KEMAMPUAN PEMAHAMAN KONSEP PADA MATAKULIAH GEOMETRI ANALITIK BIDANG
}

\author{
Desniarti $^{1}$, Ramadhani ${ }^{2}$ \\ ${ }^{1,2}$ Universitas Muslim Nusantara Al Washliyah \\ Email 1: desniarti82@gmail.com \\ Email 2 : ramah.math@gmail.com
}

\begin{abstract}
Abstrak
Geogebra adalah salah satu aplikasi perpaduan antara geometri dan aljabar. Aplikasi ini merupakan aplikasi yang sudah dapat di install dari play store dari Handphone android. Sehingga aplikasi ini sangat baik digunakan dalam proses pembelajaran matematika, khususnya untuk kemampuan pemahaman konsep pada materi parabola dan hiperbola. Tujuan penelitian ini adalah untuk mengetahui pengaruh Geogebra terhadap kemampuan pemahaman konsep matematis. Metode penelitian ini adalah quasi eksperimen. Instrumen yang digunakan dalam penelitian ini adalah tes kemampuan pemahaman konsep matematis. Anlisis yang digunakan dalam penelitian ini akan di analisis dengan analisis regresi. Hasil penelitian menunjukkan ada pengaruh Geogebra terhadap kemampuan pemahaman konsep matematis.
\end{abstract}

Kata Kunci : Geogebra, Kemampuan Pemahaman Konsep

\begin{abstract}
Geogebra is an application of a combination of geometry and algebra. This application is an application that can be installed from the play store from an Android mobile. So that this application is very well used in the learning process of mathematics, especially for the ability to understand concepts in parabolic and hyperbolic matter. The purpose of this study was to determine the effect of Geogebra on the ability to understand mathematical concepts. This research method is quasiexperimental. The instrument used in this study is a test of the ability to understand mathematical concepts. The analysis used in this study will be analyzed by regression analysis. The results showed that there was an influence of Geogebra on the ability to understand mathematical concepts.
\end{abstract}

Keywords: Geogebra, Concept Understanding Ability

\section{PENDAHULUAN}

Pentingnya mempelajari matematika, karena matematika menjadi salah satu pelajaran yang diikutsertakan dalam ujian mulai Ujian Nasional (UN), Seleksi Bersama
Penerimaan Mahasiswa Perguruan Tinggi Negeri (SBMPTN), seleksi Calon Pegawai Negeri Sipil (CPNS) dan lain sebagainya. Selain itu, dalam kehidupan sehari-hari tidak terlepas dari matematika misalanya dalam jual 
beli. Hal ini, sejalan dengan yang diungkapkan oleh Cornelius ${ }^{1}$ "Lima alasan perlunya belajar matematika meliputi: (1) sarana berpikir yang jelas dan logis; (2) sarana untuk memecahkan masalah dalam kehidupan sehari-hari; (3) sarana mengenal pola-pola hubungan dan generalisasi pengalaman; (4) sarana untuk mengembangkan kreativitas; dan (5) sarana untuk meningkatkan kesadaran terhadap perkembangan budaya".

Berdasarkan uraian diatas pelajaran matematika sangat penting untuk dipelajari. Salah satu tujuan dari pembelajaran matematika adalah untuk meningkatakan kemampuan berpikir khususnya kemampuan pemahaman konsep matematis.

Namun kenyataannya, kemampuan pemahaman konsep masih rendah. Rendahnya kemampuan pemahaman konsep menurut Wahyudin adalah kurang memiliki kemampuan materi prasyarat yang baik, kurang memiliki kemampuan untuk memahami serta mengenali konsep-konsep dasar matematika, kurang memiliki kemampuan dan ketelitian dalam menyimak atau mengenali sebuah persoalan matematika, kurang memiliki kemampuan menyimak kembali sebuah jawaban yang diperoleh (apakah jawaban itu mungkin / tidak), kurang memiliki kemampuan bernalar yang logis dalam menyelesaikan persoalan atau soal matematika ${ }^{3}$.

Untuk meningkatkan kemampuan pemahaman konsep matematis dapat diterapkannya aplikasi Geogebra. Aplikasi ini sekarang sudah dapat di download atau instal dari Playstore yang ada pada handphone Android. Kita tahu bahwa anak didik sekarang sudah memiliki Android. Oleh karena itu, meraka dapat mengunakan apalikasi ini untuk proses pembelajaran.

Geogebra dapat meningkatkan kemapuan pemahaman konsep matematis. Hal ini sesuai dengan penelitian terdahulu : (1) Pratiwi yang menyatakan bahwa aplikasi Geogebra memiliki pengaruh yang positif terhadap peningkatan pemahaman konsep matematis dalam proses pembelajaran $^{4}$, (2) dalam penelitian Lestari, siswa yang menggunakan bahan ajar dengan memanfaatkan program Geogebra mengalami peningkatan pemahaman konsep dibandingkan dengan siswa sebelum menggunakan bahan ajar. Dengan demikian, penggunaan Geogebra dapat meningkatkan kemampuan pemahaman konsep matematis ${ }^{3}$.

\section{KAJIAN TEORI}

Kemampuan pemahaman konsep merupakan salah satu kemampuan matematis yang harus dimiliki oleh seorang siswa. Kemampuan pemahaman konsep adalah kemampuan untuk memaknai pertanyaan mengapa, dari mana, atau bagaimana tentang suatu konsep pembelajaran.

Depdiknas menyatakan indikator yang menunjukan pemahaman konsep antara menurut Lestariantara lain: a) menyatakan ulang sebuah konsep; b) mengklasifikasi objek-objek menurut sifat-sifat tertentu (sesuai dengan konsepnya); c) memberi contoh dan 
non contoh dari konsep; d) Menyajikan konsep dalam berbagai bentuk representasi matematis; e) mengembangkan syarat perlu dan syarat cukup suatu konsep; f) menggunakan, memanfaatkan, dan memilih prosedur atau operasi tertentu; g) mengaplikasikan konsep atau algoritma pemecahan masalah ${ }^{3}$.

Dengan demikian indikator pemahaman konsep dalam penelitian ini adalah:

1. Membuat kembali konsep matematis

2. Mengklasifikasi objek menurut karakteristiknya

3. Menyajikan konsep dalam berbagai ide matematis

4. Memilih prosedur atau rumus tertentu

5. Mengaplikasikan konsep atau rumus untuk pemecahan masalah.

Dalam era globalisasi seperti sekarang ini, pemanfaat teknologi dalam proses pembelajaran matematika sudah menjadi hal yang penting. Karena dengan bantuan teknologi proses pembelajaran mudah untuk tercapai. Salah satu teknologi yang digunakan untuk proses pembelajaran matematika adalah Geogebra. Geogebra sangat cocok digunakan untuk materi yang berkaitan dengan Geometri dan Aljabar. Sehingga aplikasi ini sangat bemanfaat bagi guru dan siswa.

Geogebra merupakan aplikasi yang tidak komersil, sehingga setiap orang yang menginstal tidak harus memnayar. Apalagi di zaman sekarang ini, Geogebra sudah dapat di install dari Android. Sehingga siswa atau guru tidak harus menggunakan komputer atau laptop untuk mengoperasikannya. Selain itu menurut Mahmudi (dalam Khotimah) ${ }^{5}$, GeoGebra menawarkan kesempatan yang efektif untuk mengkreasi lingkungan belajar online interaktif yang memungkinkan siswa mengeksplorasi berbagai konsepkonsep matemati.

Keunggulan GeoGebra dalam pembelajaran matematika diantaranya adalah sebagaai berikut ${ }^{5}$ : a) dapat menghasilkan lukisan- lukisan geometri dengan cepat dan teliti dibandingkan dengan menggunakan pensil, penggaris, atau jangka, b) adanya fasilitas animasi dan gerakangerakan manipulasi (dragging) pada GeoGebra dapat memberikan pengalaman visual yang lebih jelas kepada siswa dalam memahami konsep geometri, c) dapat dimanfaatkan sebagai balikan/evaluasi untuk memastikan bahwa lukisan yang telah dibuat benar, d) mempermudah guru/siswa untuk menyelidiki atau menunjukkan sifat - sifat yang berlaku pada suatu objek geometri.

\section{METODE PENELITIAN}

Penelitian ini menggunakan pendekatan penelitian kuantitatif dengan metode eksperimen dalam bentuk kuasi eksperimen. Penelitian ini bertujuan menelaah tentang pengaruh penggunaan aplikasi Geogebraterhadap kemampuan pemahaman konsep matematis.

Dalam penelitian kuasi eksperimen ini dilakukan dengan melalui beberapa tahap yang diawali dengan studi pendahuluan yang digunakan untuk merumuskan 
identifikasi masalah, rumusan masalah studi literatur yang pada akhirnya diperoleh perangkat penelitian berupa bahan ajar, pembelajaran serta instrumen penelitian. Sebelum dilakuakan tindakan penelitian terlebih dahulu dilakukan dengan memberikan prettes berupa tes kemampuan pemahaman konsep matematis(pretes). Kemudian dilakukan perlakuan pembelajaran dengan penggunaan aplikasi Geogebra. Selanjutnya, peneliti memberikan postes kemampuan pemahaman konsep matematis.Sehingga Pretes dan postes yang nantinya akan dianalisis secara kualitatif dengan uji korelasi dan regresi. Sedangkan data kuantitatif diperoleh dari pretes dan postes untuk setiap data kemampuan pemahaman konsep matematis mahasiswa. Kedua data ini, kualitatif dan kuantitatif digunakan bersama dan apabila dibandingkan masing-masing dapat digunakan untuk keperluan penyusunan pembahasan hasil penelitian dan laporan akhir penelitian.

Populasi penelitian ini adalah mahasiswa Semester III Pendidikan Matematika di Fakultas Keguruan dan Ilmu Pendidikann di Universitas Muslim Nusantara (UMN) AlWashliyah Tahun Ajaran 2018/2019 sebanyak 90 mahasiswa. Sampel Penelitian adalah Mahasiswa Semester III H sebanyak 30 orang. Penelitian ini menggunakan instrumen tes kemampuan pemahaman konsep matematis yang berupa soal essay yang terdiri dari 4 butir soal. Untuk mempermudah penskoran, berikut pedoman penskoran tes kemampuan pemahaman konsep pada Tabel 1 berikut:

Tabel 2. Pedoman Penskoran Tes Kemampuan Pemahaman Konsep Matematis

\begin{tabular}{|c|l|}
\hline \multicolumn{1}{|c|}{ Indikator dan Skor } & \multicolumn{1}{c|}{ Keterangan } \\
\hline Skor 0 & $\begin{array}{l}\text { Tidak ada jawaban atau tidak menuliskan kembali } \\
\text { konsep matematis yang sesuai dengan soal }\end{array}$ \\
\hline Skor 1 & $\begin{array}{l}\text { Menuliskan kembali konsep matematis, namun } \\
\text { masih banyak terdapat kesalahan. }\end{array}$ \\
\hline Skor 2 & $\begin{array}{l}\text { Menuliskan kembali konsep yang sesuai dengan } \\
\text { defenisi suatu objek, namun masih terdapat } \\
\text { kesalahan }\end{array}$ \\
\hline Skor 3 & $\begin{array}{l}\text { Menuliskan kembali konsep matematis yang } \\
\text { sesuai dengan soal secara tepat dan benar }\end{array}$ \\
\hline Mengklasifikasi objek menurut karakteristik sesuai dengan konsepnya \\
\hline Skor 0 & $\begin{array}{l}\text { Tidak ada jawaban atau tidak menuliskan ide } \\
\text { matematis yang sesuai dengan soal }\end{array}$ \\
\hline Skor 1 & $\begin{array}{l}\text { Menuliskan ide matematis, namun belum dapat } \\
\text { mengklasifikasinnya menrut karakteristik sesuai }\end{array}$ \\
\hline
\end{tabular}




\begin{tabular}{|c|c|}
\hline & dengan konsepnya \\
\hline Skor 2 & $\begin{array}{l}\text { Dapat mengklasifikasikan objek sesuai dengan } \\
\text { karakteristinya, namun masih terdapat beberapa } \\
\text { kesalahan }\end{array}$ \\
\hline Skor 3 & $\begin{array}{l}\text { Dapat mengklasifikasikan objek sesuai dengan } \\
\text { karakteristinya sesuai dengan konsepnya secara } \\
\text { tepat dan benar }\end{array}$ \\
\hline \multicolumn{2}{|c|}{ Menyajikan konsep dalam berbagai representasi matematis } \\
\hline Skor 0 & $\begin{array}{l}\text { Tidak ada jawaban atau tidak menuliskan ide } \\
\text { konsep matematis yang sesuai dengan soal }\end{array}$ \\
\hline Skor 1 & $\begin{array}{l}\text { Menuliskan ide matematis, namun belum dapat } \\
\text { menyajikan konsep dalam berbagai represenatsi } \\
\text { matematis }\end{array}$ \\
\hline Skor 2 & $\begin{array}{l}\text { Dapat menyajikan konsep dalam berbagai } \\
\text { representasi matematis, namun masih terdapat } \\
\text { kesalahan }\end{array}$ \\
\hline Skor 3 & $\begin{array}{l}\text { Dapat menyajikan konsep dalam berbagai } \\
\text { representasi matematis secara tepat dan benar }\end{array}$ \\
\hline \multicolumn{2}{|c|}{ Memilih prosedur atau rumus tertentu } \\
\hline Skor 0 & $\begin{array}{l}\text { Tidak ada jawaban atau tidak menuliskan ide } \\
\text { konsep matematis yang sesuai dengan soal }\end{array}$ \\
\hline Skor 1 & $\begin{array}{l}\text { Menuliskan ide matematis yang sesuai dengan } \\
\text { soal, namun belum dapat menentukan prosedur } \\
\text { atau rumus yang sesuai dengan konspenya }\end{array}$ \\
\hline Skor 2 & $\begin{array}{l}\text { Dapat memilih prosedur atay rumus yang sesuai } \\
\text { dengan konsepnya, namun masih terdapat } \\
\text { kesalahan }\end{array}$ \\
\hline Skor 3 & $\begin{array}{l}\text { Dapat memilih prosedur atay rumus yang sesuai } \\
\text { dengan konsepnya yang tepat dan benar }\end{array}$ \\
\hline \multicolumn{2}{|c|}{ Mengaplikasikan konsep atau rumus untuk pemecahan masalah } \\
\hline Skor 0 & $\begin{array}{l}\text { Tidak ada jawaban atau tidak menuliskan ide } \\
\text { konsep matematis yang sesuai dengan soal }\end{array}$ \\
\hline Skor 1 & $\begin{array}{l}\text { Menuliskan ide matematis namun belum dapat } \\
\text { mengaplikasikan konsep dalam pemecahan } \\
\text { masalah }\end{array}$ \\
\hline Skor 2 & $\begin{array}{l}\text { Dapat mengaplikasikan konsep namun masih } \\
\text { banyak kesalahan dalam pemecahan masalah }\end{array}$ \\
\hline
\end{tabular}




\begin{tabular}{|l|l|}
\hline Skor 3 & $\begin{array}{l}\text { Dapat mengaplikasikan konsep dalam pemecahan } \\
\text { masalah, namun terdapat sedikit kesalahan }\end{array}$ \\
\hline Skor 4 & $\begin{array}{l}\text { Dapat mengaplikasikan konsep dalam pemecahan } \\
\text { masalah secara tepat dan benar }\end{array}$ \\
\hline
\end{tabular}

\section{HASIL DAN PEMBAHASAN}

$\begin{array}{ccr}\text { Hasil tes } & \text { kemampuan } \\ \text { pemahaman } & \text { konsep } & \text { matematis }\end{array}$

(KPKM) ini diberikan kepada 30 orang mahasiswa. Pada tes KPKM skor maksimal yang diperoleh mahasiswa adalah 52 dan jika di konversikan ke dalam nilai menjadi 100. Tujuan diberikan pretes adalah untuk menegtahui kemampuan awal mahasiswa sebelum pembelajaran dilaksanakan dengan bantuan software Geogebra. Dan postes diberikan kepada mahasiswa setelah proses pembelajaran, untuk mengetahui pengeruh Geogebra terhadap kemampuan pemahaman konsep matematis. Hasil pretes dan postes KPKM dengan SPSS dapat dilihat pada Tabel 2 dibawah ini.

Tabel 2. Hasil Pretes Kemampuan Pemahaman Konsep Matematis Descriptive Statistics

\begin{tabular}{|l|r|r|r|r|r|r|}
\hline & N & Minimum & Maximum & Sum & Mean & Std. Deviation \\
\hline Pretes_KPKM & 30 & 32,00 & 42,00 & 1070,00 & 35,6667 & 2,98656 \\
Postes_KPKM & 30 & 45,00 & 52,00 & 1434,00 & 47,8000 & 2,29542 \\
Valid N (listwise) & 30 & & & & & \\
\hline
\end{tabular}

Berdasarkan tabel diatas terlihat bahwa nilai minimum dan maksimum pada pretes KPKM adalah 32,00 dan 42,00. Sedangkan nilai minimum dan maksimum pada postes KPKM sebesar 42, dan 52.00. Hal ini menunjukkan bahwa nilai postes lebih tinggi daripada nilai pretes. Nilai rata-rata pretes KPKM sebesar 35,6667 dan postes KPKM 47,80. Sehingga, nilai postes lebih tinggi daripada nilai pretes. Dengan demikian, pembelajaran dengan Geogebra dapat mempengaruhi kemampuan pemahaman konsep matematis mahasiswa.
Sebelum menghitung analisis data untuk uji hipotesis, akan di hitung dengan uji prasyarat. Uji prasyarat dalam penelitian ini adalah uji normalitas, uji homogenitas dan uji linieritas.

Kriteriapengujian,jikasignifikanyang diperolehlebihbesardari0,05, makasampelberasaldaripopulasiyang berdistribusinormaldanjikasignifikan yangdiperolehlebihkecildari0,05makas ampelbukanberasaldaripopulasi yang berdistribusinormal.Untukmengujihipo tesistersebutdigunakanuji KolmogorovSmirnov. sedangkan hasilperhitungan dengan IBM Statistic SPSS 23tersajikan padaTabel 3berikut 
Tabel 3. Uji Normalitas Kemampuan Pemahaman Konsep

Tests of Normality

\begin{tabular}{|c|c|c|c|c|c|c|}
\hline & \multicolumn{3}{|c|}{ Kolmogorov-Smirnov ${ }^{\mathrm{a}}$} & \multicolumn{3}{|c|}{ Shapiro-Wilk } \\
\hline & Statistic & Df & Sig. & Statistic & Df & Sig. \\
\hline $\begin{array}{l}\text { Pretes_KPKM } \\
\text { Postes_KPKM }\end{array}$ & $\begin{array}{l}, 122 \\
136\end{array}$ & $\begin{array}{l}30 \\
30\end{array}$ & $\begin{array}{r}, 200^{*} \\
162\end{array}$ & $\begin{array}{l}, 928 \\
905\end{array}$ & $\begin{array}{l}30 \\
30\end{array}$ & $\begin{array}{l}, 045 \\
, 011\end{array}$ \\
\hline
\end{tabular}

*. This is a lower bound of the true significance.

a. Lilliefors Significance Correction

Berdasarsarkan tabel diatas, dapat terlihat bahwa hasil sig. pretes (tes sebelum pembelajaran Geogebra) dan postes (tes sesudah pembelajaran Geogebra) kemampuan pemahaman konsep matematis sebesar 0,200 dan 0,162 . Karena kedua nilai sig. tersebut lebih besar dari 0,05 maka data tersebut berdistribusi normal. sehingga uji prasyarat ini terpenuhi.

Uji prasyarat selanjutnya adalah uji homogenitas.

Kriteriauntukpengujianhomogenitasde nganmenggunakanujiLeveneStatistic sebagai berikut :

Jika nilai signifikan > 0,05 , makavarian kelompok data homogen.

Jika nilai signifikan $<0,05$, makavarian kelompok data tidak homogen.

Hasil perhitungan homogenitas dengan IBM Statistic SPSS 23ditampilkan pada Tabel 4 berikut:

Tabel 4. Uji Homogenitas KPKM

Test of Homogeneity of Variances

Nilai_KPKM

\begin{tabular}{|c|c|c|c|}
\hline $\begin{array}{c}\text { Levene } \\
\text { Statistic }\end{array}$ & df1 & df2 & Sig. \\
\hline 2,275 & 1 & 58 &, 137 \\
\hline
\end{tabular}

Berdasarkan tabel di atas, bahwa nilai sig. kemampuan pemahaman konsepsebelum (pretes) dan sesudah pembelajaran Geogebra (postes) adalah 0,137 . Sehingga nilai sig. 0,137 > 0,05 maka hasil kemampuan pemahaman konsep tersebutberdistribusi sama (varians homogen).

Uji linieritas merupakan uji prasyarat yang digunakan dalam penelitian ini. Kriteria uji linieritas adalah jika nilai Deviation from Linearity sig. > 0,05, makaada hubungan linier secara signifikan. Dan jika nilai Deviation from Linearity sig. $<0,05$, maka tidak ada hubungan linier secara signifikan. Hasil uji linieritas di hitung dengan menggunakan IBM Statistic 23, hasilnya pada tabel 5 berikut:

Tabel 5. Uji Linieritas Kemampuan Pemahaman Konsep

ANOVA Table

\begin{tabular}{|c|c|c|c|c|c|c|c|}
\hline & & & $\begin{array}{l}\text { Sum of } \\
\text { Squares }\end{array}$ & df & $\begin{array}{l}\text { Mean } \\
\text { Square }\end{array}$ & $\mathrm{F}$ & Sig. \\
\hline \multirow{5}{*}{$\begin{array}{l}\text { Pretes_KPKM * } \\
\text { Postes_KPKM }\end{array}$} & \multirow{3}{*}{$\begin{array}{l}\text { Between } \\
\text { Groups }\end{array}$} & (Combined) & 83,117 & 6 & 13,853 & 1,815 &, 140 \\
\hline & & Linearity & 33,927 & 1 & 33,927 & 4,445 &, 046 \\
\hline & & Deviation from Linearity & 49,190 & 5 & 9,838 & 1,289 & ,303 \\
\hline & \multicolumn{2}{|c|}{ Within Groups } & 175,550 & 23 & 7,633 & & \\
\hline & \multicolumn{2}{|l|}{ Total } & 258,667 & 29 & & & \\
\hline
\end{tabular}

Berdasarkan tabel diatas, nilai sig. deviation from linearity sebesar
0,303 . Sehingga niali sig. deviation from linearity lebih besar dari 0,05 . 
Dengan demikian ada hubungan linier kemampuan pemahaman konsep dengan pembelajaran Geogebra.

Setelah uji prasyarat terpenuhi selanjutnya untuk uji hipotesis penelitian ini dengan uji korelasi. Hasil uji korelasi kemampuan pemahaman konsep matematis di hitung dengan IBM Statistic 23, hasilnya pada tabel berikut:

Tabel 6. Hasil Analisis Korelasi Kemampuan Pemahaman Konsep Correlations

\begin{tabular}{|ll|r|r|}
\hline & & Postes_KPKM & Pretes_KPKM \\
\hline Postes_KPKM & Pearson Correlation & 1 &, $362^{*}$ \\
& Sig. (2-tailed) & &, 049 \\
& $\mathrm{~N}$ & 30 & 30 \\
\hline Pretes_KPKM & Pearson Correlation &, $362^{*}$ & 1 \\
& Sig. (2-tailed) &, 049 & 30 \\
& $\mathrm{~N}$ & 30 & \\
\end{tabular}

*. Correlation is significant at the 0.05 level (2-tailed).

Berdasarkan tabel diatas di peroleh nilai korelasi product moment sebesar 0,362. Hal ini menunjukkan bahwa terdapat pengaruh pembelajaran dengan Geogebra terhadap kemampuan pemahaman konsep matematis mahasiswa. Namun, pengaruh Geogebra ini masih lemah

terhadap kemampuan pemahamn konsep matematis.

Selanjutnya, data hasil kemampuan pemahaman konsep matematis akan di analisis dengan regresi. Hasil regresi dihitung dengan menggunakan aplikasi IBM Statistic 23 pada tabel 7 berikut:

Tabel 7. Hasil Analisis Regresi

Coefficients $^{\mathrm{a}}$

\begin{tabular}{|c|c|c|c|c|c|c|}
\hline \multirow{2}{*}{\multicolumn{2}{|c|}{ Model }} & \multicolumn{2}{|c|}{ Unstandardized Coefficients } & \multirow{2}{*}{$\begin{array}{c}\begin{array}{c}\text { Standardized } \\
\text { Coefficients }\end{array} \\
\text { Beta }\end{array}$} & & \multirow[b]{2}{*}{ Sig. } \\
\hline & & $\mathrm{B}$ & Std. Error & & & \\
\hline \multirow[t]{2}{*}{1} & (Constant) & 37,872 & 4,845 & & 7,816 & 000 \\
\hline & Pretes_KPKM & 278 &, 135 & ,362 & 2,056 & 049 \\
\hline
\end{tabular}

Berdasarkan tabel di atas diperoleh persamaan regresinya yaitu $Y=37,876+0,278 x$. Artinya konstanta sebesar 37,872 menyatakan bahwa jika tidak ada nilai pretes kemampuan pemahaman konsep matematis maka nilai postesnya sebesar 37,872 dan koefisien regresi $\mathrm{X}$ sebesar 0,471 menyatakan bahwa setiap penambahan 1 pada nilai pretes kemampuan pemahaman konsep maka nilai postesnya bertambah sebesar 0,278 .

Hasil penelitian uang ditemukan menunjukkan bahwa penggunaan Geogebra dalam proses pembelajaran dapat mempengaruhi kemampuan pemahaman konsep matematis mahasiswa. Hal ini dikarenakan nilai sebelum pembelajaran (pretes) lebih rendah dari sesudah pembelajaran (postes) dengan menggunakan 
Geogebra. Hasil nilai rata-rata pretes dan postes mahasiswa dapat terlihat pada tabel dibawah ini:

Tabel 8. Hasil Pretes dan Postes Butir Soal

\begin{tabular}{|l|c|c|}
\hline $\begin{array}{l}\text { Butir } \\
\text { Soal }\end{array}$ & $\begin{array}{c}\text { Pretes } \\
\text { KPKM }\end{array}$ & $\begin{array}{c}\text { Postes } \\
\text { KPKM }\end{array}$ \\
\hline Soal 1 & 7,37 & 10,70 \\
\hline Soal 2 & 8,30 & 12,13 \\
\hline Soal 3 & 9,27 & 12,17 \\
\hline Soal 4 & 10,73 & 12,83 \\
\hline Rerata & 8,92 & 11,96 \\
\hline
\end{tabular}

Berdasarkan tabel diatas, terlihat bahwa nilai mahasiswa pada setiap butir soal kemampuan pemahamn konsep matematis sebelum pembelajaran sebesar 7,37 (soal 1), 8,30 (soal 2), 9,27 (soal 3), 10,73 (soal 4) dan 8,92 (rerata). Sedangakan pada nilai postes (sesudah pembelajaran dengan Geogebra) pada soal $1(10,70)$, soal $2(12,13)$, soal $3(12,17)$ soal 4 $(12,83)$ dan nilai rata-rata setiap soal sebesar 11,96. Untuk lebih jelasnya perhatikan Gambar dibawah ini

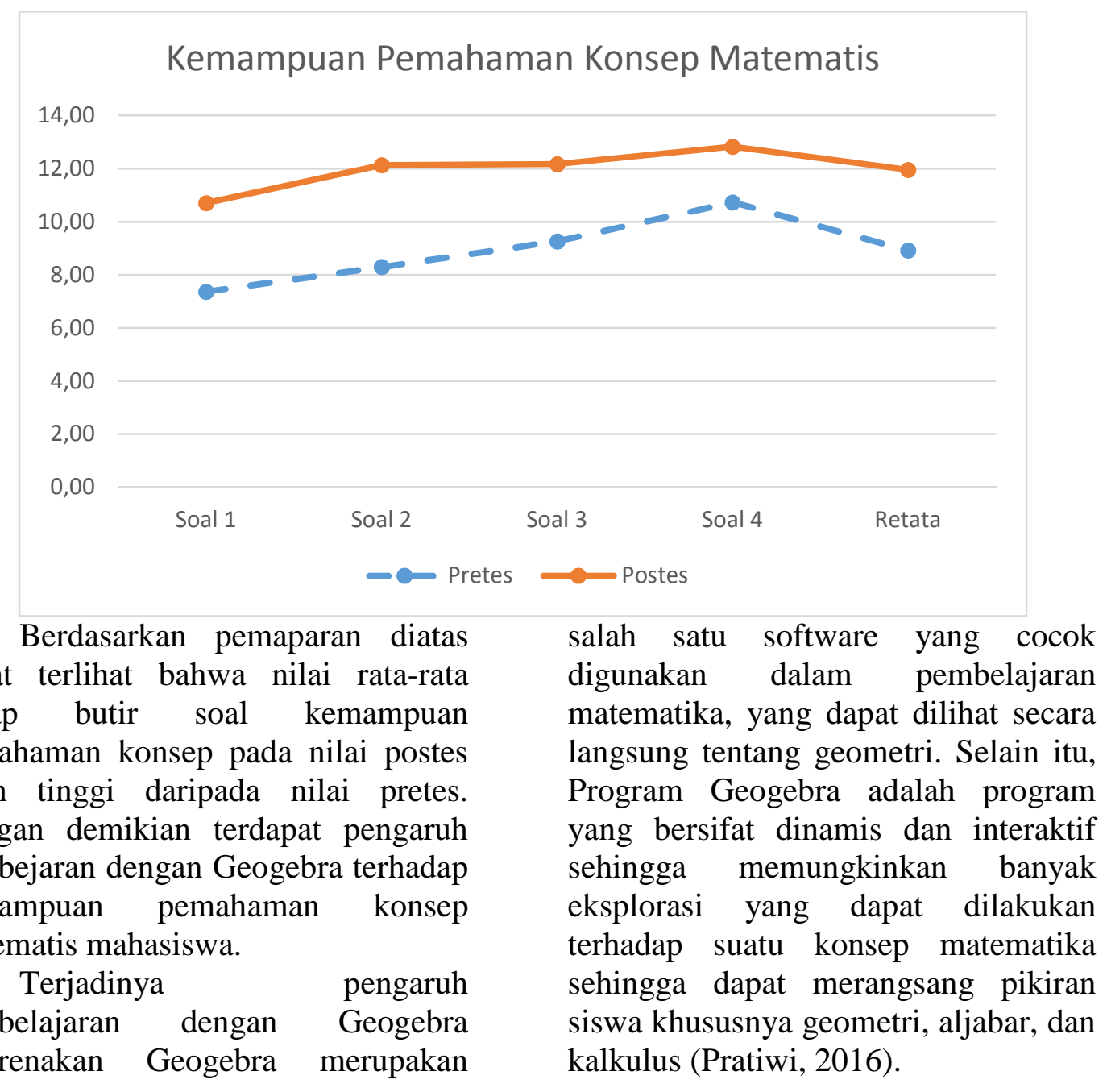

dapat terlihat bahwa nilai rata-rata setiap butir soal kemampuan pemahaman konsep pada nilai postes lebih tinggi daripada nilai pretes. Dengan demikian terdapat pengaruh pembejaran dengan Geogebra terhadap kemampuan pemahaman konsep matematis mahasiswa.

\begin{tabular}{lrr}
\multicolumn{2}{c}{ Terjadinya } & pengaruh \\
pembelajaran & dengan & Geogebra \\
dikarenakan & Geogebra & merupakan
\end{tabular}




\section{DAFTAR PUSTAKA}

1. Abdurrahman, M. 2006. .Pendidikan Bagi Anak Berkesulitan Belajar. Jakarta: Penerbit Rineka Cipta.

2. Badan Standar Nasional Pendidikan. 2006.Standar Isi Untuk Satuan Pendidikan Dasar dan Menengah. Jakarta

3. Lestari, I., 2018. Pengembangan Bahan Ajar Matematika dengan Memanfaatkan Geogebra Untuk Meningkatkan Kemampuan Pemahaman Konsep. Gaus: Jurnal Pendidikan Matematika Vol. 01 No, 01 Mei 2018. P2620-95X, e-2620-8067
4. Pratiwi, D.D. 2016. Pembelajaran Learning Cycle 5e Berbantuan Geogebra terhadap Kemampuan Pemahaman Konsep Matematis. Al-Jabar: Jurnal Pendidikan Matematika, Vol. 7, No. 2, Hal 191 - 202.

5. Khotimah. 2018. Meningkatkan Kemampuan Literasi Matematis dengan Pendekatan Metacognitive Guidance Berbatuan Geogebra. Gaus: Jurnal Pendidikan Matematika Vol. 01 No, 01 Mei 2018. P2620-95X, e-2620-8067 